\title{
KOMBINASI EKSTRAK HERBA Andrographis paniculata (Burm f.) Nees DAN DAUN Pandanus amaryllifolius Roxb. SEBAGAI ANTIHIPERGLIKEMIA
}

\author{
EXTRACT COMBINATIONS of Andrographis paniculata (Burm f.) Nees \\ HERBS AND Pandanus amaryllifolius Roxb. LEAVES \\ AS ANTI-HYPERGLYCEMIC
}

\author{
Ni Putu Ermi Hikmawanti*, Hadi Sunaryo, Rachmad Eka Prasetyo \\ Fakultas Farmasi dan Sains, Universitas Muhammadiyah Prof. DR. Hamka \\ Alamat: Jl. Delima II/IV Islamic Center Klender, Jakarta 13460 \\ *Penulis Korespondensi, email: ermy0907@uhamka.ac.id
}

\begin{abstract}
ABSTRAK
Herba Andrographis paniculata (Burm f.) Nees atau sambiloto dan daun Pandanus amaryllifolius (Burm f.) Nees atau pandan wangi telah diketahui khasiatnya sebagai antihiperglikemia. Penelitian bertujuan untuk mengoptimasi kombinasi ekstrak etanol $70 \%$ herba sambiloto dan daun pandan wangi sebagai antihiperglikemia pada tikus jantan galur Sprague Dawley yang diinduksi aloksan. Hewan uji dibagi menjadi 7 kelompok perlakuan, masing-masing kelompok terdiri dari 4 ekor tikus. Kelompok I adalah kelompok tanpa perlakuan; kelompok II mendapatkan glibenklamid dosis 0,26 $\mathrm{mg} / \mathrm{Kg} \mathrm{BB}$; kelompok III mendapatkan ekstrak herba sambiloto tunggal dosis 1000 $\mathrm{mg} / \mathrm{Kg} \mathrm{BB}$; kelompok IV mendapatkan ekstrak daun pandan wangi tunggal dosis 600 $\mathrm{mg} / \mathrm{Kg} \mathrm{BB}$; kelompok V, VI, dan VII masing-masing mendapatkan kombinasi ekstrak herba sambiloto dan daun pandan wangi dosis berturut-turut 1000:300, 500:300, dan 500:600 mg/Kg BB. Pemeriksaan kadar gula darah menggunakan sampel serum darah tikus yang diukur dengan metode GOD-PAP dan dibaca dengan spektrofotometer klinikal mikrolab 300. Preparat jaringan pankreas diamati menggunakan mikroskop dengan perbesaran 40x untuk melihat ada tidaknya vacuolation dan nekrosis pada sel pulau Langerhans pankreas. Data persentase penurunan kadar gula darah tikus dianalisis menggunakan ANOVA satu arah dan dilanjutkan dengan uji Tukey. Gambaran histopatologi pankreas dianalisis secara deskriptif. Hasil penelitian menunjukkan bahwa kelompok yang mendapatkan kombinasi ekstrak herba sambiloto dan daun pandan wangi (500:300 mg/Kg BB) merupakan kelompok kombinasi yang lebih baik dari kelompok ekstrak tunggalnya $(\mathrm{p}<0,05)$ dan sebanding dengan kelompok kontrol positif glibenklamid $(p>0,05)$ dalam menurunkan kadar gula darah. Semua kelompok kombinasi ekstrak mampu memberikan perbaikan sel pulau Langerhans pankreas tikus.
\end{abstract}

Kata kunci: Andrographis paniculata (Burm.f.) Nees., Antihiperglikemia, Kombinasi, Pandan wangi, Sambiloto, Pandanus amaryllifolius Roxb.

\section{ABSTRACT}

Andrographis paniculata (Burm.f.) Nees or sambiloto herbs and Pandanus amaryllifolius Roxb. or pandan wangi leaves has been known to its anti-hyperglicemic activities. This study aimed to optimize the combinations from $70 \%$ ethanol extract of 
sambiloto herbs and pandan wangi leaves as anti-hyperglicemic in Sprague Dawley male rats induced by alloxan. The rats were divided into 7 groups, each containing 4 animals. Group I is a group without treatment; group II received glibenclamide at a dose of $0.26 \mathrm{mg} / \mathrm{Kg} \mathrm{BW}$; group III received sambiloto herbs extract at a dose of 1000 $\mathrm{mg} / \mathrm{Kg} \mathrm{BW}$; group IV received pandan wangi leaves extract at a dose $600 \mathrm{mg} / \mathrm{Kg} \mathrm{BW}$; groups V, VI, and VII each received combinations of sambiloto herbs extract and pandan wangi leaves extract in ratio 1000:300, 500:300, and 500:600 $\mathrm{mg} / \mathrm{Kg} \mathrm{BW}$, respectively. Blood glucose level of rat blood serum samples was measured using GODPAP method and read using mikrolab 300 clinical spectrophotometer. The pancreatic tissue preparations were observed using a microscope (40x magnification) to identify the presence of vacuolation and necrosis of the Langerhans cells of the pancreas. The percentage data of rat blood glucose level was analyzed using the one-way ANOVA test and followed by the Tukey test. The pancreatic histopathologic was analyzed descriptively. The results showed that the group that received combinations of sambiloto herbs and pandan wangi leaves extracts 500:300 $\mathrm{mg} / \mathrm{Kg} \mathrm{BW}$ was a better combination group than the single extract groups $(p<0.05)$ and was comparable to glibenclamide as positive control in decrease blood glucose level. All the extract combinations groups are able to provide pancreatic Langerhans cells repair in rats.

Keywords: Andrographis paniculata, anti-hyperglicemic, combinations, pandan wangi, blood glucose level, sambiloto, Pandanus amaryllifolius

\section{PENDAHULUAN}

Diabetes melitus (DM) merupakan penyakit gangguan metabolik menahun akibat pankreas tidak memproduksi cukup insulin atau tubuh tidak dapat menggunakan insulin yang diproduksi secara efektif. Insulin adalah hormon yang mengatur keseimbangan kadar gula darah. Jika insulin terganggu maka akan mengakibatkan peningkatan konsentrasi glukosa di dalam darah (hiperglikemia) (Depkes RI, 2014). Menurut International Diabetes Federation (IDF), pada tahun 2013 terdapat 382 juta orang mengalami diabetes di dunia. Jumlah tersebut diperkirakan akan meningkat pada tahun 2035 menjadi 592 juta orang. Diperkirakan dari 382 juta orang tersebut, 175 juta diantaranya belum terdiagnosis, sehingga terancam berkembang progresif menjadi komplikasi tanpa disadari dan tanpa pencegahan (Depkes RI, 2014). Banyak cara yang telah digunakan untuk membantu mengatasi DM, salah satunya dengan menggunakan obat tradisional. Herba Andrographis paniculata Ness. atau herba sambiloto dan daun Pandanus amaryllifolius Roxb. atau daun pandan wangi merupakan tanaman dapat digunakan untuk tujuan tersebut.

Sambiloto merupakan tanaman yang temasuk famili Acanthaceae. Kandungan yang terdapat pada herba sambiloto adalah andrografolida, flavonoid, diterpenoid, $\alpha-$ sitosterol, dan lain-lain (Joselin dan Jeeva, 2014; Hossain et al., 2014). Herba sambiloto memiliki banyak khasiat, salah satunya adalah mengobati diabetes. Sambiloto dilaporkan memiliki aktivitas farmakologi yang kuat termasuk salah satu diantaranya sebagai antihiperglikemia (Hossain et al., 2014). Ekstrak etanol 95\% herba sambiloto terbukti dapat menurunkan kadar gula darah sebesar 50\% pada hewan uji dengan dosis $1 \mathrm{~g} / \mathrm{KgBB}$ (Ahmad et al., 2007).

Daun pandan wangi merupakan tanaman obat dari family Pandaneceae juga memiliki khasiat untuk mengobati diabetes dengan kandungan senyawa volatil, 
alkaloid, flavonoid, tanin, dan polifenol (Routray dan Rayaguru, 2010; Prameswari dan Widjanarko, 2014). Daun pandan wangi memiliki aktivitas antidiabetes sebesar $30 \%$ dan aktivitas antioksidan pada ekstrak air daun pandan wangi sebesar 66,82\%. Ekstrak air daun pandan wangi terbukti dapat menurunkan kadar gula darah dan dapat memperbaiki sel Langerhans yang rusak pada hewan uji dengan dosis $600 \mathrm{mg} / \mathrm{Kg} \mathrm{BB}$ (Prameswari dan Widjanarko, 2014).

Berdasarkan latar belakang tersebut, adanya kecenderungan bahwa semakin tinggi dosis maka akan semakin besar pula aktivitas antidiabetesnya. Penelitian ini ingin membuktikan bahwa kombinasi ekstrak etanol $70 \%$ herba sambiloto dan daun pandan wangi dengan pemberian dosis yang lebih rendah pada masing-masing ekstrak mampu menurunkan kadar gula darah dan perbaikan sel Langerhans pankreas dengan efek yang optimal dibanding pemberian ekstrak tunggalnya.

\section{METODE PENELITIAN}

\section{Alat dan Bahan}

Bahan uji yang digunakan adalah simplisia herba sambiloto yang diperoleh dari Merapi Farma Herbal, Yogyakarta dan simplisia daun pandan wangi yang diperoleh dari Balai Penelitian Tanaman Rempah dan Obat (BALITRO), Bogor pada bulan April 2017. Kedua tanaman dideterminasi di Balai Penelitian dan Pengembangan Botani "Herbarium Bogoriense" LIPI, Bogor.

Hewan uji yang digunakan adalah tikus jantan galur Sprague Dawley yang berumur 2-3 bulan dengan bobot 200-300 g sejumlah 28 ekor yang diperoleh dari Institut pertanian Bogor (IPB) bagian Produksi Ternak Daging Kerja dan Aneka Ternak.

Bahan-bahan kimia lain seperti: etanol 70\%, aloksan monohidrat, Na CMC, aquadest, ketamin, glibenklamid (PT. Kimia Farma).

\section{Jalannya Penelitian}

Pembuatan Ekstrak Herba Sambiloto dan Daun Pandan Wangi

Serbuk simplisia herba sambiloto sebanyak $960 \mathrm{~g}$ dan daun pandan wangi sebanyak $1000 \mathrm{~g}$ masing-masing dimaserasi secara terpisah menggunakan etanol $70 \%$. Masing-masing maserat kemudian diuapkan pelarutnya dengan menggunakan vacuum rotary evaporator hingga diperoleh ekstrak kental (Depkes RI 2008). Masing-masing ekstrak kental dihitung persentase rendemennya terhadap simplisia yang diekstraksi. Kadar air masing-masing ekstrak ditetapkan menggunakan metode destilasi yang dilakukan di BALITTRO, Bogor.

Penapisan Fitokimia

Penapisan fitokimia dilakukan untuk menguji keberadaan kelompok senyawa alkaloid, saponin, tanin, flavonoid, dan terpenoid. Larutan uji dibuat dalam etanol. Prosedur identifikasi seperti pada Hanani (2016).

Pengujian Antihiperglikemia

Protokol pengujian dengan nomor: 17-05-0488 telah lolos kaji etik dan disetujui oleh Komite Etik Penelitian Kesehatan Fakultas Kedokteran Universitas Indonesia dengan nomor surat: 455/UN2.F1/ETIK/2017. Sebelum diberi perlakuan percobaan, hewan uji diaklimatisasi di dalam kandang dan diberi pakan dan minum standar dari 
hari ke-1 sampai ke-7. Hari ke-8, semua kelompok uji diinduksi aloksan monohidrat secara intraperitonial $160 \mathrm{mg} / \mathrm{Kg} \mathrm{BB}$.

Sebanyak 28 ekor tikus dibagi menjadi 7 kelompok. Masing-masing kelompok terdiri dari 4 ekor. Hari ke-9 sampai dengan hari ke-13, semua kelompok uji diberikan pakan dan minum standar. Hari ke-14, semua kelompok uji diambil darahnya dan diukur kadar gula darahnya. Hari ke-15 sampai dengan hari ke-28, semua kelompok diberi perlakuan, dengan ketentuan: Kelompok I adalah kelompok tanpa perlakuan yang hanya diberi larutan Na-CMC; kelompok II mendapatkan glibenklamid dosis 0,26 $\mathrm{mg} / \mathrm{Kg} \mathrm{BB}$; kelompok III mendapatkan ekstrak herba sambiloto tunggal dosis 1000 $\mathrm{mg} / \mathrm{Kg} \mathrm{BB}$; kelompok IV mendapatkan ekstrak daun pandan wangi tunggal dosis 600 $\mathrm{mg} / \mathrm{Kg} \mathrm{BB}$; kelompok V, VI, dan VII masing-masing mendapatkan kombinasi ekstrak herba sambiloto dan daun pandan wangi dosis berturut-turut 1000:300, 500:300, dan $500: 600 \mathrm{mg} / \mathrm{Kg} \mathrm{BB}$.

Pemberian bahan uji dilakukan per oral. Hari ke-29, semua kelompok uji diambil darahnya dan diukur kadar gula darahnya. Hari ke-30, dilakukan pembedahan tikus dan pengamatan histopatologi sel Langerhans pankreas.

Pengukuran Kadar Gula Darah

Serum diambil sebanyak $10 \mu \mathrm{L}$, dicampur dengan reagen enzim GOD-PAP (glucose liquicolor kit dari HUMAN-diagnostic) sebanyak $1000 \mu \mathrm{L}$, kemudian divortex dan diinkubasi selama 10 menit pada suhu $25^{\circ} \mathrm{C}$. Kadar gula darah dibaca dengan spektrofotometer klinikal mikrolab 300. Persentase penurunan kadar gula darah menggunakan rumus 1 .

$$
\text { Penurunan kadar gula darah }(\%)=\frac{a-b}{a} \times 100 \%
$$

Keterangan: $\quad \mathrm{a}=$ kadar hiperglikemia

$\mathrm{b}=$ kadar gula darah setelah diberikan bahan uji

Pengamatan Histopatologi Pankreas

Proses pembedahan dilakukan pada tikus yang telah dianestesi dengan ketamin. Tahap pembuatan preparat jaringan meliputi: pengambilan organ pankreas, fiksasi, dehidrasi, penjernihan (clearing), pencetakan (embedding), pemotongan, pewarnaan (staining), penutupan sediaan. Preparat jaringan diamati ada tidaknya vacuolation dan nekrosis pada sel pulau Langerhans pankreas menglgunakan mikroskop (Olympus x21) dengan perbesaran 40x.

\section{Analisis Data}

Data persentase penurunan kadar gula darah dianalisis homogenitas varian dan normalitasnya, kemudian jika data terbukti terdistribusi normal dan homogen maka selanjutnya data tersebut dianalisis dengan uji ANOVA satu arah dengan taraf signifikasi $95 \%(\alpha=0,05)$ untuk mengetahui adanya perbedaan yang bermakna dan dilanjutkan dengan uji Tukey. Gambaran histopatologi pankreas dianalisis secara deskriptif.

\section{HASIL DAN PEMBAHASAN}

Hasil ekstraksi herba sambiloto dan daun pandan wangi beserta persentase rendemen dan kadar air ekstraknya dapat dilihat pada Tabel I. 
Tabel I. Hasil ekstraksi, rendemen, dan kadar air ekstrak herba sambiloto dan daun pandan wangi

\begin{tabular}{clcc}
\hline No & \multicolumn{1}{c}{ Jenis } & Herba Sambiloto & Daun Pandan Wangi \\
\hline 1 & Berat serbuk simplisia $(\mathrm{g})$ & 960 & 1000 \\
2 & Berat ekstrak kental $(\mathrm{g})$ & 210 & 166 \\
3 & Rendemen ekstrak $(\%)$ & 21,80 & 16,60 \\
4 & Kadar air $(\%)$ & 7,37 & 9,17 \\
\hline
\end{tabular}

Besar kecilnya nilai rendemen menunjukkan keefektifan proses ekstraksi. Efektifitas proses ekstraksi dipengaruhi oleh metode ekstraksi yang di gunakan, waktu ekstraksi, suhu, kemurnian pelarut, konsentrasi pelarut dan polaritas pelarut. Etanol 70\% sebagai pelarut pengekstraksi dapat menarik senyawa aktif fenolik dan flavonoid lebih baik dari pelarut air. Dibandingkan etanol murni, etanol $70 \%$ lebih banyak menarik senyawa flavonoid karena kepolarannya (Tiwari et al., 2011).

Hasil penapisan fitokimia ekstrak herba sambiloto dan daun pandan wangi dapat dilihat pada Tabel II. Hasil menunjukkan bahwa ekstrak etanol $70 \%$ herba sambiloto mengandung senyawa alkaloid, tanin, flavonoid, terpenoid, dan saponin, sedangkan daun pandan wangi mengandung senyawa flavonoid dan terpenoid.

Tabel II. Hasil Penapisan Fitokimia Ekstrak Herba Sambiloto dan Daun Pandan Wangi

\begin{tabular}{ccc}
\hline Senyawa yang dideteksi & $\begin{array}{c}\text { Ekstrak etanol 70\% } \\
\text { herba sambiloto }\end{array}$ & $\begin{array}{c}\text { Ekstrak etanol 70\% daun } \\
\text { pandan wangi }\end{array}$ \\
\hline Alkaloid & + & - \\
Flavonoid & + & + \\
Tanin & + & - \\
Terpenoid & + & + \\
Saponin & + & - \\
\hline
\end{tabular}

Ket: $(+)=$ mengandung senyawa yang dideteksi, $(-)=$ tidak mengandung senyawa yang dideteksi

Gambar 1 menunjukkan grafik rerata kadar gula darah tikus sebelum dan setelah perlakuan. Berdasarkan grafik tersebut, semua kelompok perlakuan mengalami penurunan kadar gula darah setelah 14 hari perlakuan. 


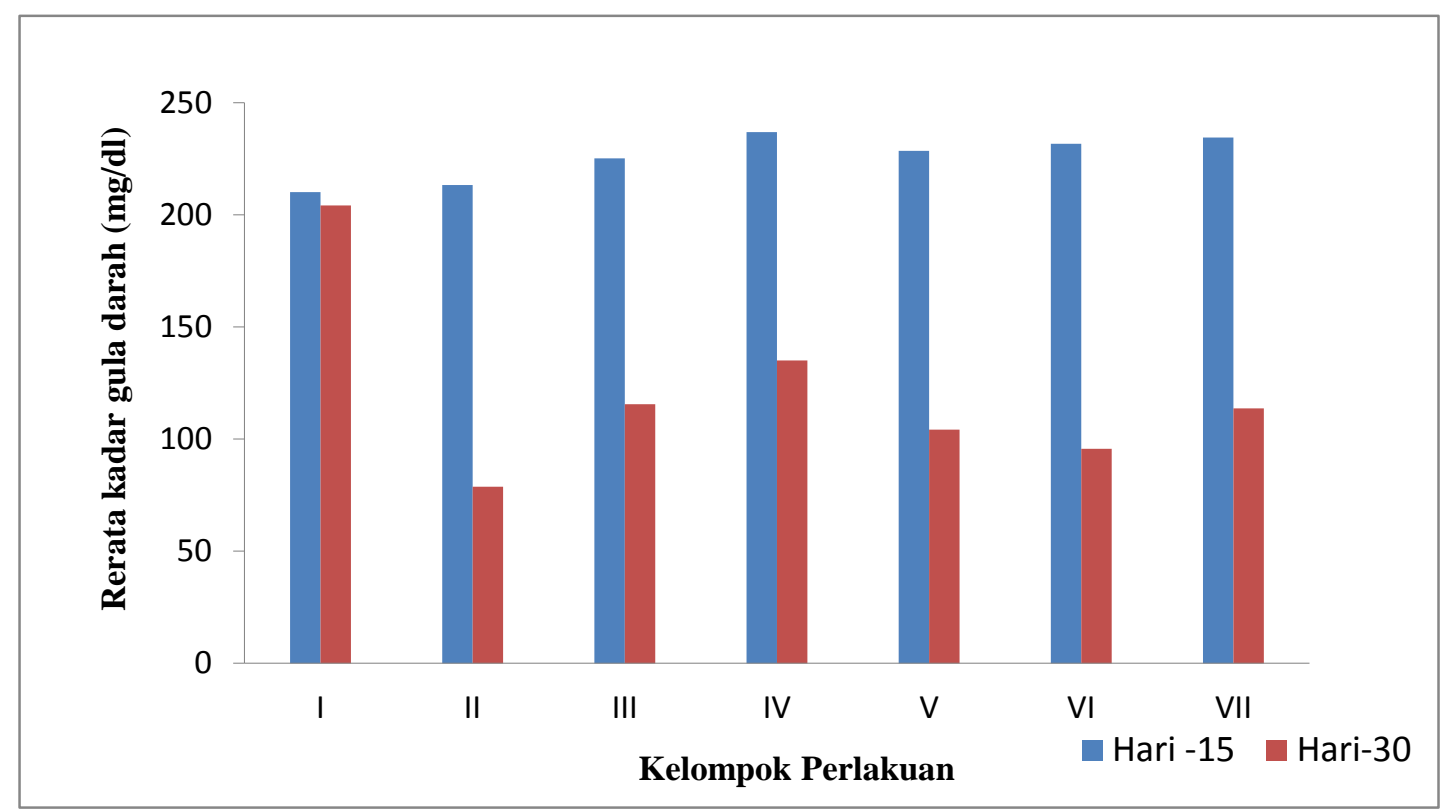

Gambar 1. Grafik Rerata Kadar Gula Darah (Mg/Dl) Tikus Tiap Kelompok Sebelum Perlakuan (Hari Ke-15) dan Setelah Perlakuan (Hari Ke-30)

Selanjutnya, persentase penurunan kadar gula darah semua kelompok perlakuan yang dihitung terhadap kadar gula darah hiperglikemia (sebelum perlakuan) dapat dilihat pada Tabel III. Data persentase penurunan kadar gula darah diuji normalitas dan homogenitasnya dengan Klomogrov-Smirnov $(\alpha=0,05)$. Hasil menunjukkan bahwa data yang diperoleh terdistribusi normal dan homogen. Selanjutnya dilakukan analisa dengan uji ANOVA satu arah untuk mengetahui apakah ada perbedaan yang bermakna atau tidak pada setiap kelompok perlakuan dengan ketentuan $\mathrm{p}<0,05$. Hasil analisa diperoleh nilai sig $=0,000(<0,05)$. Berdasarkan hasil tersebut menunjukkan bahwa pemberian ekstrak maupun kombinasi ekstrak mempunyai pengaruh secara bermakna terhadap penurunan kadar gula darah pada tikus yang diinduksi aloksan. Analisis dilanjutkan dengan uji Tukey. Hasil analisis statistik menunjukkan bahwa tidak terdapat perbedaan bermakna antara kelompok yang mendapatkan glibenklamid dengan kelompok VI yang mendapatkan kombinasi ekstrak etanol $70 \%$ herba sambiloto $500 \mathrm{mg} / \mathrm{Kg}$ BB dan daun pandan wangi $300 \mathrm{mg} / \mathrm{Kg} \mathrm{BB}$.

Tabel III. Persentase Penurunan Kadar Gula Darah Tikus Tiap Kelompok Setelah 14 Hari Perlakuan

\begin{tabular}{lc}
\hline Perlakuan & $\begin{array}{c}\text { Persentase Penurunan Kadar } \\
\text { Gula Darah }(\%) \pm \text { SD }\end{array}$ \\
\hline Kelompok I & $2,86 \pm 0,0081$ \\
Kelompok II & $63,02 \pm 0,0136$ \\
Kelompok III & $48,70 \pm 0,0183$ \\
Kelompok IV & $42,94 \pm 0,0204$ \\
Kelompok V & $54,46 \pm 0,0179$ \\
Kelompok VI & $58,72 \pm 0,0265$ \\
Kelompok VII & $51,57 \pm 0,0247$ \\
\hline
\end{tabular}


Gambar 2 menunjukkan penampang histopatologi pankreas tikus setelah 14 hari perlakuan dengan pewarnaan Hematoksilin Eosin yang diamati di bawah mikroskop dengan perbesaran 40x. Gambar 2 (A) adalah penampang histopatologi kelompok tanpa perlakuan. Pada gambar tesebut tampak tanda panah berwarna kuning menunjukkan ruang-ruang kosong yang berarti terjadi nekrosis pada sel pulau Langerhans pankreas dengan ukuran sel cukup kecil, jumlah sedikit dan tersusun renggang. Hal tersebut menunjukkan bahwa pemberian Na CMC selama 14 hari tidak memperbaiki sel pulau Langerhans pankreas. Kondisi ini mengindikasikan bahwa tikus mengalami gangguan terhadap produksi insulin sehingga menyebabkan tikus tetap dalam kondisi hiperglikemia. Gambar 2 (B), (C), (D), (E), (F), dan (G) menunjukkan tidak adanya nekrosis pada sel pulau Langerhans pankreas pada kelompok perlakuan, di mana ukuran sel besar, jumlah sel banyak dan tersusun rapat. Hal ini menunjukkan bahwa pemberian glibenklamid, ekstrak tunggal mapuselama 14 hari pada tikus yang diinduksi aloksan dapat memperbaiki sel pulau Langerhans pankreas tikus. Hal ini berarti bahwa baik pemberian ekstrak tunggal herba sambiloto dan ekstrak tunggal daun pandan wangi maupun kelompok kombinasi ekstrak I, II, dan III dapat memperbaiki sel pulau Langerhans pankreas tikus.

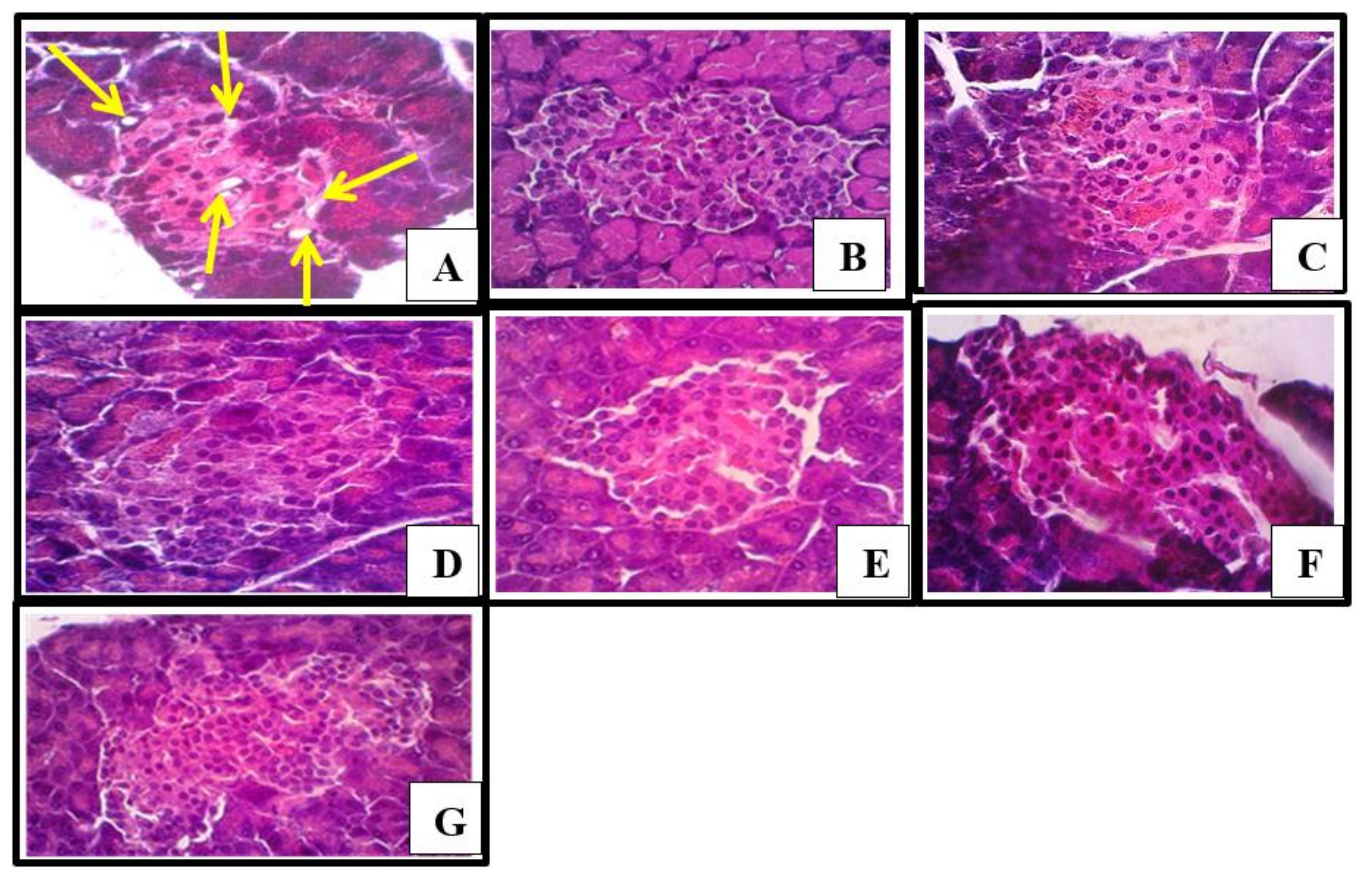

Gambar 2. Penampang Histopatologi Pankreas Tikus (Perbesaran 40x) Setelah 14 Hari Perlakuan Dengan Pewarnaan Hematoksilin Eosin

Keterangan: (A) kelompok I, (B) kelompok II, (C) kelompok III, (D) kelompok IV, (E) kelompok $V,(F)$ kelompok VI, $(G)$ kelompok VII. Tanda panah berwarna kuning menunjukkan ruang-ruang kosong yang berarti terjadi nekrosis pada sel pulau Langerhans pankreas.

Aloksan adalah derivat urea yang menyebabkan kerusakan secara selektif pada sel $\beta$-pankreas yang memproduksi insulin (Rohilla dan Shahjad 2012). Glibenklamid merupakan suatu antidiabetes oral kelompok golongan sulfonilurea. Kelompok ini bekerja meningkatkan sensitivitas sel $\beta$-pankreas (Bösenberg dan Van 2008).

Ekstrak etanol pandan dan pepaya telah terbukti menurunkan hiperglikemia pada mencit yang diinduksi streptozotosin. Hasil pewarnaan histologi menunjukkan ekstrak 
tersebut secara signifikan menginduksi regenerasi sel- $\beta$ sebagaimana dibuktikan dengan penurunan kadar glukosa darah. Kandungan flavonoid, alkaloid, saponin dan tanin diduga sebagai komponen bioaktifnya (Chang et al. 2013).

Telah diketahui pula bahwa ekstrak sambiloto dan andrografolida efektif sebagai antihiperglikemia dengan menurunkan kadar gula darah melalui penghambatan $\alpha$ glycosidase and $\alpha$-amylase, meningkatkan sensitivitas insulin serta peredam radikal bebas dari sirkulasi yang mengganggu integritas membran. Senyawa bioaktif lain yang juga beraktivitas sebagai antihiperglikemia adalah 14-deoksi-11,12didehidroandrografolida (Hossain et al., 2014).

Flavonoid dapat menurunkan kadar glukosa darah dengan kemampuannya sebagai zat antioksidan. Flavonoid bersifat protektif terhadap kerusakan sel $\beta$ sebagai penghasil insulin serta dapat meningkatkan sensitivitas insulin. Antioksidan dapat menekan apoptosis sel $\beta$ tanpa mengubah proliferasi dari sel $\beta$ pankreas (Kaneto et al., 1999). Antioksidan pada flavonoid dapat menyumbangkan atom hidrogennya. Flavonoid akan teroksidasi dan berikatan dengan radikal bebas sehingga radikal bebas menjadi senyawa yang lebih stabil (Panjuantiningrum 2010). Peran flavonoid sebagai antioksidan alami diduga mampu menangani komplikasi akibat keadaan hiperglikemia seperti autooksidasi glukosa dan peroksidasi lipid yang selanjutnya dapat meningkatkan pembentukan senyawa oksigen reaktif yang umum dikenal dengan Reactive Oxygen Species (ROS) (Mshelia, 2004). Flavonoid dapat menurunkan kadar gula darah dengan meningkatkan sekresi insulin dan mengurangi penyerapan glukosa. Flavonoid bersifat sebagai zat antioksidan sehingga protektif terhadap kerusakan sel $\beta$ pankreas sebagai penghasil insulin serta dapat meningkatkan sensitivitas insulin dan meregenerasi sel pulau Langerhans pankreas (Kaneto et al. 1999, Arjadi dan Susatyo 2010).

\section{KESIMPULAN}

Kombinasi ekstrak etanol $70 \%$ herba sambiloto $(500 \mathrm{mg} / \mathrm{Kg} \mathrm{BB})$ dan daun pandan wangi dosis (300 mg/Kg BB) mampu menurunkan kadar gula darah sebesar 58,72\% yang sebanding dengan glibenklamid $(0,26 \mathrm{mg} / \mathrm{Kg} \mathrm{BB})$ pada tikus putih jantan galur Sprague Dawley dan memiliki aktivitas lebih baik dari pemberian masing-masing ekstrak tunggalnya. Semua kelompok kombinasi ekstrak mampu memberikan perbaikan sel pulau Langerhans pankreas tikus.

\section{DAFTAR PUSTAKA}

Ahmad, M., Razak, A., Akowuah, G.A., Asmawi, Z., Zhari, I., 2007, HPLC Profile and Antihyperglycemic Effect of Ethanol Extracts of Andrographis paniculata in Normal and Sterptozotocin-induced Diabetic Rats, Journal of Natural Medicine, 61(4): 422-429.

Arjadi, F., Susatyo, P., 2007, Regenerasi Sel Pulau Langerhans Pada Tikus Putih (Rattusnorvegicus) Diabetes yang Diberi Rebusan Daging Mahkota Dewa (Phaleria macrocarp (scheff.) Boerl.), Sains Medika Journal of Medicine and Health, 2(2): 117-126.

Bösenberg L .H. and Van Zyl, D.G. 2008. The mechanism of action of oral antidiabetic drugs: A review of recent literature, Journal of Endocrinology, Metabolism and Diabetes of South Africa, 13(3): 80-88. 
Chang, C.L.T., Lin Y., Bartolome A., Chen Y-C., Chiu AC., and Yang, W-C. 2013. Review Article: Herbal Therapies for Type 2 Diabetes Mellitus: Chemistry, Biology, and Potential Application of Selected Plants and Compounds. EvidenceBased Complementary and Alternative Medicine. 1-33.

Depkes RI, 2008, Farmakope Herbal Indonesia Edisi I. Departemen Kesehatan RI: Jakarta.

Depkes RI, 2014, Pusat data dan informasi Kementerian Kesehatan RI, www.depkes.go.id, diakses 12 Januari 2017.

Hanani, E., 2016, Analisis Fitokimia, Penerbit Buku Kedokteran EGC: Jakarta.

Hossain, S., Urbi, Z., Sule, A., Rahman, K.M.H., 2014. Review Article Andrographis paniculata (Burm. f.) Wall. ex Nees: A Review of Ethnobotany, Phytochemistry, and Pharmacology, The Scientific World Journal: 1-28.

Joselin, J., Jeeva, S., 2014, Andrographis paniculata: A Review of its Traditional Uses, Phytochemistry and Pharmacology, Medicinal \& Aromatic Plants, 3(4): 1-15.

Kaneto, H., Kajimoto, Y., Miyagawa, J., Matsuoka, T., Fujitani, Y., Umayahara, Y., Hanafusa, T., Matsuzawa, Y., Yamasaki, Y., Hori, M., 1999, Beneficial effect of antioxidant in diabetes: Possible protection of pancreatic $\beta$-Cells againt glucose toxicity, Diabetes, 48: 2398-2406.

Mshelia, D.S., 2004, Role of free radicals in pathogenesis of diabetes nephropathy. Annals of African Medicine, 3(2): 55-62.

Panjuantiningrum, F., 2010, Pengaruh Pemberian Buah Naga Merah (H. Polyrhizus) terhadap kadar gula darah tikus putih yang diinduksi aloksan, Skripsi, Fakultas Kedokteran Universitas Sebelas Maret, Surakarta.

Prameswari OK, Widjanorko SB. 2014, Uji Efek Ekstrak Air Daun Pandan Wangi Terhadap Penurunan Kadar Glukosa Darah dan Hispatologi Tikus Diabetes, Jurnal Pangan dan Agroindustri: 16-27.

Rohilla A. and Shahjad A. 2012. Alloxan Induced Diabetes: Mechanisms and Effects. International Journal of Research in Pharmaceutical and Biomedical Sciences. 3(2): 819-823.

Routray, W., Rayaguru, K., 2010, Chemical Constituens and Post-Harvest Prospect of Pandanus amaryllifolius Roxb. leaves: A Review, Journal Food Reviews International, 26(3): 230-245.

Tiwari, P., Kumar, B., Kaur, M., Kaur, G., Kaur, H., 2011. Phytochemical Screening and Extraction: A Review, Internationale Pharmaceutica Sciencia, 1(1): 98-106. 